IRA-International Journal of Management \& Social Sciences

ISSN 2455-2267; Vol.04, Issue 01 (2016)

Institute of Research Advances

http://research-advances.org/index.php/RAJMSS

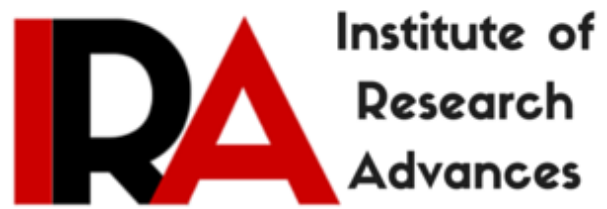

\title{
A Comparative Study of Indian Companies Act, 2013 and Companies Act of Republic of Maldives, 1996
}

\author{
Dr. Rajesh Kumar Agrawal, \\ Director, \\ Centre for Corporate Governance, Research and Training (CCGRT), \\ The Institute of Company Secretaries of India (ICSI), \\ Navi-Mumbai, Maharashtra, India.
}

DOI: http://dx.doi.org/10.21013/jmss.v4.n1.p9

\section{How to cite this paper:}

Agrawal, R. (2016). A Comparative Study of Indian Companies Act, 2013 and Companies Act of Republic of Maldives, 1996. IRA-International Journal of Management \& Social Sciences (ISSN 2455-2267), 4(1). doi:http://dx.doi.org/10.21013/jmss.v4.n1.p9

(C) Institute of Research Advances

\section{(c)) EY-NC}

This works is licensed under a Creative Commons Attribution-Non Commercial 4.0 International License subject to proper citation to the publication source of the work.

Disclaimer: The scholarly papers as reviewed and published by the Institute of Research Advances (IRA) are the views and opinions of their respective authors and are not the views or opinions of the IRA. The IRA disclaims of any harm or loss caused due to the published content to any party. 


\begin{abstract}
Any law in force in a country indicates its social, economic and political position. Law is considered to be the measure by which a country's progress is taken into account. India has adopted Companies Act, 2013 in place of the Companies Act, 1956 considering the changing needs of the society and to facilitate the ease of business. The Companies Act of the Republic of Maldives 1996 governs the formation, registration and management of companies in the Republic of Maldives. In this paper, an attempt is made to bring out the comparative picture of India and Maldives with regard to Indian Companies Act, 2013 and The Companies Act of the Republic of Maldives 1996 respectively. This paper throws some light on the framework of The Companies Act of the Republic of Maldives 1996 and Indian companies Act 2013 and the rapid challenges faced by both the countries and also to understand the basic difference in various concepts and application of the act in both the countries. The finding of the study shows that India has got verge in terms of adoption of Corporate Laws and Corporate Governance compliances and also has wider provisions than the Maldives Companies Act, 1996.
\end{abstract}

Keywords: Incorporation, One Person Company, Meetings, Directors, Company Secretary, Corporate Social Responsibility, Woman Director, Compromise, Arrangements and Amalgamation.

\title{
1. INTRODUCTION
}

Over the years, the Indian Companies Act has undergone many changes which have helped in building a strong corporate culture and it has helped to make sure that the spirit of corporate culture has not surpassed government laws and regulations. The Companies Act of the Republic of Maldives is the law governing the formation, registration and management of companies in the Republic of Maldives. On the basis of the comparative study of Indian companies Act, 2013 and the Companies Act of the Republic of Maldives, 1996 in depth knowledge regarding the framework of different companies act had been possible. This has helped in the thorough study of Companies Act of two different countries which has entailed to compare different concepts.

The Indian Companies Act is basically prepared in Hindi and English languages while the Companies Act of Republic of Maldives is basically prepared in Dhivehi language which is an Indo-Aryan language predominantly spoken by about 350,000 people in the Republic of Maldives and the Companies Act of Republic of Maldives is also available in English language. In India, Ministry of Corporate Affairs is primarily concerned with administration of the Companies Act 2013, the Companies Act 1956, the Limited Liability Partnership Act, 2008 \& other allied Acts and rules \& regulations framed there-under mainly for regulating the functioning of the corporate sector in accordance with law. MCA (Ministry of Corporate Affairs) also protects investors and offers may important services to stakeholders. In the Republic of Maldives, the Ministry of Economic Development is entrusted with the mandate to develop and promote inclusive and sustainable economic growth to Maldives, through prudent policies and favourable business climate. It is the objective of the Ministry to create opportunities for the growth of enterprises and individuals and to provide leadership and coordination within the government's overall economic policy making process and also provide the necessary policy as well as regulatory environment, to nurture and foster trade, investments and growth to the country.

The Parliament of India regular passes and amends regulations for both businesses and investors. In addition to provisions from the Companies Act of 1956, now the Companies Act of 2013 features provisions regarding mergers and acquisitions, board room decision-making, members meetings, related party transactions, corporate social responsibility, and shareholding. The act was further amended through the Companies (Amendment) Act, 2015 which eliminated the procedural common seal, declarations for commencement of businesses, and minimum paid-up capital requirements. The amendment also relaxed governing-related party transactions while limiting access to strategic corporate resolutions in India, but in some cases the ministry of India has made strict rules for the protection the interest of general public i.e. punishment for contravention of section 73 or section 76 
which are relates to company fail to repay the deposit or part there of or any interest due thereon after the specified time period.

Maldives is a multi-party constitutional democracy. Economic growth is projected around $4 \%$ in 2014.The Republic of Maldives comprises 1,190 islands in 20 atolls spread over $900 \mathrm{~km}$ in the Indian Ocean. The Maldives attracts a million tourists annually, and tourism is the growth engine for the economy and accounts for about 70\% of GDP. The source of law in the Maldives is based on constitution and on the Islamic Sharia. Bills passed by the Citizen Majlis (the Parliament) become law after ratification by the President. The President is also empowered by the Constitution to legislate by decree.

Therefore, in this research paper an attempt has been made to bring out the comparative analysis of Indian Companies Act, 2013 and the Companies Act of the Republic of Maldives 1996 and the various concepts related to the corporate scenario of both the countries.

\section{OBJECTIVES OF THE STUDY}

a) To compare the Indian Companies Act, 2013 and The Companies Act of the Republic of Maldives, 1996.

b) To know the various developments in both the countries related to Companies Act.

c) To compare the corporate world under their respective governed act.

d) To improve the corporate governance, ensuring greater accountability and transparency.

e) To understand the basic difference in various concepts and application of the act in both the countries.

\section{RESEARCH METHODOLOGY}

The present study is an attempt to understand the basic differences in both the countries Companies Act to ensure greater flexibility, accountability and transparency. This study is based on the information collected from various secondary sources such as books, bare acts, magazines, newspaper articles, research journals available online and various websites in order to achieve its objectives.

The study covers the comparative analysis of Indian Companies Act, 2013 and The Companies Act of the Republic of Maldives, 1996. The scope of the study covers the following:

- Incorporation

- One person Company (OPC)

- Meetings

- Directors

- Company Secretary

- Auditors

- Corporate Social Responsibility (CSR)

- Woman Director

- Compromises, Arrangements and Amalgamations

\section{COMPARATIVE ANALYSIS}

\section{Incorporation}

- Incorporation is the process of declaring a corporate entity as separate from its owners. In India, a new system and easy method has been introduced for incorporation of Private or Public Limited Company without waiting for making name application for reservation of name by the Registrar of Companies (Roc) by filing E-form INC-29 (single form) with the Central registration centre (CRC) which is established under Ministry of corporate affairs for 
specific objective of providing speedy incorporation related services within stipulated time frames which are in line with international best practices. Maximum three directors can file their particulars and no need to apply for DIN (Director Identification Number) of $2^{\text {nd }}$ director. Registration fees Rupees 2000 with additional fees depending upon the capital of the company. The facility to file INC-29 is optional. One can follow the procedure of application for Director Identification Number (DIN), name application (INC-1) and INC-7 (incorporation), DIR-12 (appointment of first directors of proposed company) and INC-22 (situation of registered office of company) with the Registrar of Companies, within whose jurisdiction the registered office of the company is proposed to be situated.

The present Companies Act in the Maldives allows for the incorporation of resident companies with $100 \%$ local ownership, 100\% foreign ownership and Joint Ventures between local and foreign shareholders. It also allows for the registering of a non-resident company in the Maldives for the purpose of conducting business in the country. One may apply online for the registration of companies or in person at Ministry of Economic Development (MED) and the process will take next working day from the date of application. Revenue stamp of MVR 500 is required when collecting the Registration Certificate. The documents required to be filed includes Company registration application form, taxpayer registration form (Maldives Inland Revenue Authority Form No. 101S), name search approval form, Memorandum of Association- 2 Copies, Articles of Association- 2 Copies, Acceptance letter from Managing Director, Acceptance letter from Company Secretary, National Identification card copies, Company registration as per section 7 of the Companies Act 10/96.

- In India, a company can be formed as Private Company, Public Company and One Person Company while in Maldives a company can be formed as Private company and Public Company.

- In Indian Companies Act, 2013 there is no criteria for minimum capital requirement and in the Maldives Companies Act, 1996 the minimum capital requirement for a private limited company is MVR 2,000; and minimum capital for a public limited company is MVR $1,000,000$.

- In Indian Companies Act, 2013 the maximum number of shareholders in a private company cannot exceed 200 while in the Maldives Companies Act, 1996 the number is limited to 50.

- In Indian Companies Act, 2013 there is no provision regarding registration of common seal with registrar of companies while in the Maldives Companies Act, 1996 requires all companies to make a company seal and register it with the Registrar of Companies.

- In Indian Companies Act, 2013 there is no provision regarding to filling the annual fee to ROC for continuing the registration with ROC but as per section 7 of Maldives company Act, 1996 all the Companies which are registered with ROC requires to pay annual fee to ROC as per schedule (for public companies shall pay MRf.10,000/- of Private Companies shall pay MRf. 2,000/- before the end of March every year ) otherwise ROC reserves the rights to take the necessary steps stipulated in the act to dissolved the Company.

\section{$>$ One Person Company}

One Person Company has been defined in section 2(62) of the Companies Act, 2013 which has only one person as a member and can be registered only as a Private Company and cannot be converted into section 8 company (i.e. company with charitable objects, etc) or carry out nonbanking financial activities, including investment in securities of anybody corporate An OPC cannot convert voluntarily into any kind of company unless two years have expired from the date of incorporation of One Person Company, except threshold limit (paid up share capital) is increased beyond Rs.50 Lakhs and its average annual turnover during the relevant period exceeds Rs. 2 Crores whereas there is no such concept exist in the Companies Act of Republic of Maldives, 1996.

Meetings

Board Meetings, Annual General Meeting and Extraordinary General Meetings: 
- Every company in India including One Person Company (OPC) shall hold its first board meeting within 30 days from the date of its incorporation and four subsequent board meeting in every year and maximum gap between two board meetings shall be 120 days but some exemptions are available to One person Company, Small Company and Dormant Company they requires held at least one meeting of board of Directors in each half calendar year and the gap between two meetings is not less than ninety days while in Maldives, the Board of Directors of the company shall meet at least twice a year.

- The quorum for a meeting of the Board of Directors of a company as per Companies Act, 2103 shall be $1 / 3^{\text {rd }}$ of its total strength or 2 directors, whichever is higher, and participation by video conferencing or by any other audio visual means shall also be counted while in the Maldives a majority of the Board of Directors shall constitute the quorum at a board meeting and the Act does not prevent the company from increasing the quorum by its articles of association and acting upon it.

- In Indian Companies Act, 2013 unless the articles of the company otherwise provide, the members personally present at the meeting shall elect one of themselves to be the Chairman thereof on a show of hands while in Maldives Companies act, 1996 Chairman of the board shall chair the meetings of the Board of Directors and if for any reason the Chairman is unable to attend the meeting, then directors present shall elect one of their members to be the chairman.

- A meeting of the board of directors shall be called by giving not less than seven days' notice to every director at his usual address registered with the company and such notice shall be sent by hand delivery or by post or by e-mode. Board meeting may be called at shorter notice to transact urgent business subject to condition that atleast one independent director, if any, shall be present at the meeting and in case of absence of one independent director from meeting of a board, decisions taken at such meeting shall be circulated to all directors and shall be final only on ratification thereof atleast by one independent director, if any whereas there is no such criteria present in the Companies Act of the Republic of Maldives, 1996.

- As per Indian Companies Act, 2013 there is requirements of constitute of some Committee to a specified Companies i.e. Audit Committee, Nomination and Remuneration Committee, Stakeholders Relationship Committee, Corporates Social Responsibility Committee, Independent Director Committee while as per Maldives Company Act, 1996 there is not as such provision for constitutes any committee.

- In Indian Companies Act, 2013 Minutes of every meeting of its Board of Directors or of every committee of the Board, to be prepared and signed in such manner as may be prescribed and kept within 30 days of the conclusion of every such meeting concerned while in the Companies Act of the Republic of Maldives, 1996 every company shall maintain the minutes of the meeting of Board of Directors and the minutes shall be signed by the Chairman of the meeting and the company secretary.

- In India, as per section 96 of Indian companies Act, 2013 every company other than One Person Company must hold a general meeting in each year apart from other meetings as Annual General Meeting (AGM) while in the Maldives; every company shall in each year hold a general meeting as its annual general meeting. Not more than 15 months shall elapse between the date of one annual general meeting of a company and that of the next.

- In India, the ordinary business transacted in the annual general meeting are consideration of financial Statements and reports of board of directors and Auditors, declaration of any dividend, appointment of directors in place of retiring one ,appointment of and fixation of the remuneration of the auditors. In the Maldives, the following are the ordinary business transacted- Presentation and passing of the audited balance sheet, profit and loss account and the Directors report of the company, election and appointment of directors, if any and declaration of dividends.

- A notice of 21 clear days has to be sent to all members, auditor of the Company and every director of the company. So, the audited accounts, directors report (now Board's report) has to be closed on 31st March and been posted by first week of September as per Indian Companies Act, 2013 whereas in the Maldives, every private company shall give to the shareholders at least fourteen (14) days' notice of its general meeting and very public company shall give fourteen (14) days' notice of its annual general meeting by a public announcement. 
- In Indian Companies Act, 2013 the quorum required for a public company in a general meeting is 5 members if the number of shareholders are less than 1000, 15 members if the members are 101-5000 and 30 members if the number of shareholders are more than 5000 and for a private company the quorum requirement is two members personally present in the meeting while in the Maldives a majority of the members of the company shall constitute a quorum for a general meeting and the act does not prevent a company from increasing the quorum required by its articles of association.

- In India, unless the articles of the company otherwise provide, the members personally present at the meeting shall elect one of themselves to be the Chairman thereof on a show of hands and in the Maldives, the Chairman of the Board of Directors shall chair every general meeting. If the Chairman is unable to attend the meeting then the members present shall elect one of their members to the chair.

- In India, the Board may, whenever it deems fit, call an extraordinary general meeting of the company whereas in the Maldives, a company may hold an extraordinary general meeting if its directors feel necessary to hold such a meeting.

- As per Indian Companies Act, 2013 the notice for calling EGM has to be in writing and to be given atleast 21 clear days before meeting date and in the Maldives, every private company shall give 14 days' notice of any extraordinary general meeting to its members and very public company shall give to its members 14 days' notice of any extraordinary general meeting by a public announcement.

\section{$>$ Directors}

- In Indian Companies Act, 2013 every public company shall have minimum three directors, minimum two directors in the case of a private company and one director in the case of one person company and every company shall have atleast one director who has stayed in India for a total period of not less than 182 days in previous calendar year and maximum 15 directors can be appointed in any format of Company however the company can increase the number of director beyond 15 by passing special resolution. In the Maldives, every private company shall have at least two directors and every public company shall have at least five directors in the Board and at least one member of the Board of Directors shall be a resident of the Republic of Maldives and a director of a company shall be at least sixteen years of age.

- As per Indian Companies Act, 2013 a person is allowed to be the director of a maximum of 20 companies and maximum number of public companies in which a person can be appointed as a director shall not exceed 10 which include any alternate directorship while in the Maldives Companies Act, 1996 nothing has been mentioned in this regard.

- Under section 166 of Indian Companies Act, 2013 duties and liabilities have been imposed on the directors of the companies but nothing has been mentioned in this regard under the Companies Act of Republic of Maldives, 1996.

- The articles of association should ideally mention names of the first directors of the company, if that is not done, the subscribers to the memorandum (that is, the initial shareholders who incorporate the company) shall be considered as the directors. In all other cases, the directors can be appointed by the company through a resolution passed in the general meeting and a company may, by ordinary resolution, remove a director, not being a director appointed by the Tribunal under section 242, before the expiry of the period of his office after giving him a reasonable opportunity of being heard as per Indian Companies Act, 2013 while in the Maldives Companies Act, 1996 Members to the Board of Directors shall be elected, appointed and removed in accordance with the articles of association of the company.

- A director may resign from his office by giving a notice in writing to the company and the Board shall on receipt of such notice take note of the same and the company shall intimate the Registrar in such manner, within such time and in such form as may be prescribed and shall also place the fact of such resignation in the report of directors laid in the immediately following general meeting by the company as per the Indian Companies Act, 2013 while in the Maldives Companies Act, 2013 nothing is mentioned in this regard. 
$>$ As per Indian Companies act, 2013 there is a provision for an appointment of independent directors is available to a specified companies in both Board Members and its committees for checking financial, material information, working of executive directors and protecting the interest of general public. Independent Directors approval is also requires for approving the annual accounts of the company while in the Maldives Companies Act, 1996 nothing has been mentioned in this regards.

\section{Company Secretary}

A company having paid up capital of Rs. 5 crores or more has to mandatorily have a Company Secretary in whole time employment. The requirement to appointment of Company Secretary in Companies is mentioned in the provisions of Rule- 8 of The Companies "Appointment and Remuneration of Managerial Personnel" Chapter XIII under Section 203 of Indian Companies Act, 2013 and as per section 203 of Companies Act 2013, specified company also need to appoint whole-time-key managerial personnel (Company Secretary). If a company contravenes the provision regarding the appointment of Key Managerial personnel (KMP) under Section 203 than the company shall be punishable with the minimum fine of rupees One lakh which may extend up to rupees Five lakh and every director and KMP of the company who is in default shall be punishable with fine which may extend to rupees fifty thousand and if contravention is in continuing in nature than with a further fine of rupees one thousands for every day after the first during which the contravention continues.

In the Maldives, every company shall have a company secretary. It is the duty of the Board of Directors to see that the person appointed as the company secretary is competent to discharge the functions of the secretary of the company. Every company shall, when submitting its application for registration, submit to the registrar of companies the name of person who shall be the company secretary and an acceptance letter from the person.

The need, roles and responsibilities of a Company Secretary has been increased with the introduction of new Indian Companies Act, 2013. In the Maldives Companies Act, 1996 the duties of the company secretary shall be those prescribed by the regulations made under this Act.

\section{$>\underline{\text { Auditors }}$}

An auditor is an independent professional person qualified to perform an audit. In accounting, an auditor is someone who is responsible for evaluating the validity and reliability of a company or organization's financial statements.

- In India, it is a prime requirement as per section 139 of the Companies Act, 2013 that every company shall at the first annual general meeting appoint an auditor to the conclusion of sixth annual general meeting who can either be an individual or a firm. Appointment includes reappointment. The manner and procedure of selection of auditors by the members of the company will be such as may be prescribed. It is a mandatory condition that before such appointment is made, the written consent of the auditor to such appointment, and a certificate from him stating that the appointment, if made, shall be in accordance with the conditions as may be prescribed, shall be obtained from the auditor. In Maldives Companies Act, 1996 every company shall appoint an auditor or auditors to audit the company. Every public company and companies whose share capital is more than MRF. 1,000,000.00 shall appoint chartered accountants or certified Public Accountants approved by the Auditor General to act as their Auditors.

- The auditors in the Indian Companies Act, 2013 the auditor appointed may be removed from his office before the expiry of his term only by a special resolution of the company, after obtaining the previous approval of the Central Government in that behalf in the prescribed manner whereas in the Maldives companies the auditors of the company shall be appointed and removed at the annual general meeting of the company.

- The remuneration of the auditor of a company shall be fixed in its general meeting or in such manner as may be determined therein. It must include the expenses, if any, incurred by the auditor in connection with the audit of the company and any facility extended to him but does not include 
any remuneration paid to him for any other service rendered by him at the request of the company whereas in the Maldives the remuneration of the auditors appointed under sub-section (a) of this section shall be fixed by the company in members annual general meeting.

\section{Corporate Social Responsibility (CSR)}

Corporate social responsibility would mean asking businesses to be more practical and analyse the positive as well as negative effects of their activities and decisions on the people and society at large.

In the Companies Act of the Republic of Maldives, 1996 there is no provision for 'Corporate Social Responsibility' but there is limited but growing awareness of corporate social responsibility among the business elite. There are no non-governmental organizations that promote or monitor CSR in the country while in the Indian Companies Act, 2013 undertaking such initiatives were a voluntary step for all companies until it was mandated by the new Companies Act which came to force in the year 2013. Section 135 (1) of this Act provides that every company in India, either private or public having a net worth of Rs. 500 crore or more, or a turnover of Rs. 1,000 crore or more or net profit of Rs. 5 crore or more during any financial year. needs to spend a minimum of $2 \%$ of its average net profit for the immediately preceding three financial years on corporate social responsibility activities. As per the provision stated in the Act a company shall give preference to the local areas and those areas around which the company operates for undertaking the said CSR activities. Another statutory requirement under section 135 is the formation of a CSR Committee of the Board for monitoring the CSR policies of any company consisting of at least 3 directors (inclusive of an independent director). The Committee is required to recommend and suggest the amount of expenditure that the company must incur on the activities so specified. After considering the recommendations put forth by the Committee, the Board shall approve the CSR policy for the company.

\section{Women Director}

The second proviso to section 149 (1) of the Companies Act, 2013 makes it mandatory the every listed company shall appoint at least one woman director within one year from the commencement of the second proviso to Section 149(1) of the Act. Every other public company having paid up share capital of Rs. 100 crores or more or turnover of Rs. 300 crore or more as on the last date of latest audited financial statements, shall also appoint at least one woman director within 1 year from the commencement of second proviso to Section 149(1) of the Act. Provided further that any intermittent vacancy of woman director shall be filled-up by the Board at the earliest but not later than immediate next Board meeting or three months from the date of such vacancy whichever is later. The companies complying with the norms on or after October 1, 2015 will have to pay INR $1,42,000$ along with an additional charge of INR 5,000 per day till the date of compliance while the concept of mandatory appointment of women director on Board does not exist in the Companies Act of the Republic of Maldives, 1996.

\section{$>$ Compromise, arrangements and Amalgamation}

As per Indian Companies Act, 1956 a Company can make Compromise with their creditors, or make arrangements or Amalgamate with another Company as per the provision of Section 391 to $396 \mathrm{~A}$ it is a restructuring tool available to Indian conglomerates aiming to expand and diversify their businesses for various reasons whether it is to gain competitive advantage, reduce costs or unlock values. In commercial parlance, merger essentially means an arrangement whereby one or more existing companies merge their identity into another existing company or form a distinct new entity. Company law in India is undergoing a complete overhaul and a new law was finally passed in 2013. However, the provisions relating to mergers covered in Sections 230 to 240 are yet to be notified. Until then, this court driven process will continue to be governed by Section 391-396A of the Companies Act, 1956 and the Companies (Court) Rules, 1959 (collectively referred to as "1956 Act") While in the Maldives Companies Act, 1996 nothing is mentioned in this regards. 


\section{FINDINGS AND CONCLUSIONS}

The present study of comparative analysis between Indian Companies Act, 2013 and the Companies Act of the Republic of Maldives, 1996 shows that both the countries operate in different political, economic, social and corporate environments but the various laws and regulations made under the Indian Companies Act and Companies Act of the Republic of Maldives are made on the same parameters and the concepts are almost at par with each other except for few provisions.

It can be concluded from the above study that India being the big nation in terms of geography and corporate culture, it faces bigger challenges and opportunities than Maldives. The recent changes in the economic and financial crisis have highlighted the need for change, and in that process, Indian Companies Act, 2013 has undergone a tremendous transformation and various new provisions relating to governance, e-management, compliances and enforcement, disclosure and norms, corporate social responsibility and amendments have been made in the recent time. Indian companies Act, 2013 also introduces various new concepts also like One Person Company, Small Company, Dormant Company, Woman Directors, Class Action Suits, and Registered Valuers etc. which are not in Companies Act of the Republic of Maldives 1996.

India and Maldives both are developing countries but India being a big nation than Maldives has got an edge in terms of adoption of Corporate Laws and Corporate Governance compliances. Indian companies act provides much wider provisions in each of the concept than the Maldives companies act.

\section{REFERENCES}

- Abhyankar, M. (2015). New Simplified Process of Incorporation of Company in India. Retrieved February 04, 2016, from http://blog.abhyankarcs.com/company-formation-in-india/newsimplified-process-of-incorporation-of-company-in-india/

- Appointment of Company Secretary under the Companies Act 2013 and his Rights and Obligations. $\quad$ Retrieved $\quad$ February 04, 2016, from http://www.hpacs.com/news_events_details.aspx?event=155

- Baludi, R. (2014, April 01). Meetings under Companies Act, 2013 - Corporate Law. Retrieved February 04, 2016, from http://www.caclubindia.com/articles/meetings-under-companies-act2013-20227.asp

- Companies Act of the Republic of Maldives. Retrieved February 01, 2016, from $\mathrm{http} / / /$ investmaldives.org/investmaldives/laws-and-regulations/companies-act-of-the-republic-ofmaldives/

- Department of State: 2014 Investment Climate Statement. (2014, June). Retrieved February 03, 2016, from http://www.state.gov/documents/organization/227361.pdf

- Dhivehi. Retrieved February 02, 2016, from https://en.wikipedia.org/wiki/Dhivehi

- Ministry of Economic Development Republic of Maldives. Retrieved February 03, 2016, from http://www.trade.gov.mv/page/registration-of-companies

- Ministry of Economic Development Republic of Maldives. Retrieved February 02, 2016, from http://trade.gov.mv/page/about-us

- Ministry of Economic Development Republic of Maldives. Retrieved February 01, 2016, from http://www.trade.gov.mv/

- Ministry of Economic Development Republic of Maldives. Retrieved February 01, 2016, from http://trade.gov.mv/?lid=30

- Quorum for general meetings - section 103 of Companies Act, 2013. (2013). Retrieved February 04, 2016, from https://vramonline.wordpress.com/2013/09/17/quorum-for-general-meetingssection-103-of-companies-act-2013/ 